\title{
Chemical and mineral characteristics, bioactive compounds and antioxidant activity of blackberries grown in an organic system
}

\author{
'Federal University of Pelotas, Pelotas, Brazil \\ ${ }^{2}$ Embrapa Clima Temperado, Pelotas, Brazil \\ *Corresponding author, e-mail: souzarafaela15@yahoo.com.br
}

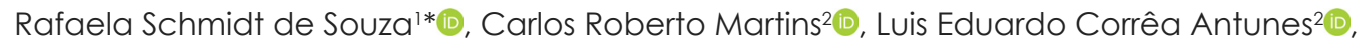

Márcia Vizzotto2 (D, Ana Cristina Richter Krolow² (D), Marcelo Barbosa Malgarim' (D)

\begin{abstract}
Blackberry bushes have increasingly drawn producers' and consumers' interest since they find their cultivation characteristics, production and nutraceutical qualities advantageous. Both chemical and mineral characteristics, bioactive compounds and antioxidant activity found in blackberries are extremely relevant factors to be considered when cultivars are chosen. Chemical analyses of the nutritional composition of fruit is important, since they can help studies of quality genotypes. Besides, fruit with high nutritional values contribute to human health when they are often consumed. This study aimed at evaluating chemical and mineral characteristics, besides bioactive compounds and antioxidant activity, of different blackberry bush genotypes grown in an organic farming system in Pelotas, Rio Grande do Sul (RS), Brazil. Production, soluble solid content, hydrogenionic potential, total titratable acidity, SS/TA ratio, minerals, phenolic compounds, anthocyanins and antioxidant activity of six blackberry bush genotypes - 'Tupy', 'BRS Xingu', Selection Black 178, Selection Black 128, Selection Black 112 and Selection Black 145 - were evaluated. It was a randomized block design with three replicates of every plant. Selection Black 178 yielded fruits with the highest value of SS/TA ratio and had the highest accumulated production. The highest anthocyanin content was found in 'BRS Xingu'. Selection Black 112 had the highest total contents of phenolic compounds and the highest antioxidant activity, whereas 'Tupy' exhibited their lowest values. Selection Black 178 adapted well to the organic farming system, a fact that did not happen to Selection Black 128.
\end{abstract}

Keywords: genotypes, macro-minerals, micro-minerals, post harvest, quality, small fruits, soluble solids

\section{Introduction}

Blackberry bushes, which belong to the family Rosaceae, yield aggregate fruits, which taste sweetacid, predominantly acid. Fruits may be consumed either fresh or industrialized, in yogurts, juices and jams. Blackberries belong to the group of small fruits, along with strawberries, blueberries, raspberry and others. Production of fresh fruit in Brazil was estimated to be 43.5 million ton in 2017. However, production is expected to increase in the coming years to over 45 million ton in the country (Hirsch et al., 2012; Brugnara, 2016; Kist, 2018; Fagherazzi et al., 2017).

Blackberry bush cultivation has increasingly drawn producers' interest due to characteristics related to production, rusticity, management and production diversification, as well as consumers' attention, since they search for healthy food and increase in fruit consumption as food complement. In addition, blackberries have high nutritional content due to their components, such as minerals, vitamins and bioactive compounds (Jacques \& Zambiazi, 2011; Antunes et al., 2014). Therefore, their regular consumption may result in health benefits and may be correlated to decrease in risks posed by noncommunicable chronic diseases (Jacques \& Zambiazi, 2011; Vizzotto, 2012).

Blackberries are highly valued not only because of their nutritional properties, but also because of their qualities, such as their taste (Brugnara, 2016). According to Raseira \& Franzon (2012), in general, most cultivars do not yield fruits that are sweet enough for the Brazilian market.

Genetic improvement of blackberry bushes started in the 1970's with a small collection of cultivars which included 'Brazos', 'Cherokee', 'Comanche' and a Uruguayan clone (with no name). Afterwards, some seeds resulting from crossings that took place at the University 
of Arkansas, located in the United States, were brought to Brazil. The Embrapa Clima Temperado has been very important in this process, mainly in the adaptation and development of new cultivars of blackberry bushes which are grown in several Brazilian areas, especially in the south and in the southeast (Hirsch et al., 2012; Antunes et al., 2014).

Qualitative characterization of fruits regarding their physico-chemical features is extremely important since they are highly related to consumers' acceptance. Commercialization forms of fruits (either fresh or processed) may be used as indicators of ripening stages, for instance (Vizzotto et al., 2012; Cruz et al., 2017).

Studies of selections and new cultivars grown in organic farming systems aim at broadening and guiding their cultivation so as to enable information to be collected and used for supporting improvement programs. The objective is not only the productivity of new cultivars, but also data on characteristics related to fruit quality, nutritional composition and the content of bioactive compounds. Besides, new genotypes which have high potential to be cultivated in agroecological farming systems can be found. As a result, researches of blackberry bush genotypes may help to show which cultivars have the best quality concerning production and desirable characteristics.

This study aimed at evaluating chemical and mineral characteristics, besides bioactive compounds and antioxidant activity, of blackberry bush genotypes grown in an organic farming system in Pelotas, Rio Grande do Sul (RS), Brazil.

\section{Material and Methods}

The experiment was carried out in the experimental field that belongs to the Embrapa Clima Temperado - latitude 31'37'9" S, longitude 52'31'33" $\mathrm{W}$ and altitude of $170 \mathrm{~m}$ - located in Pelotas, RS, Brazil. In the Köeppen climate classification, this region has a humid subtropical climate - Cfa. Its soil was classified into Argissoil, whose characteristic is an argillic (textural) B horizon with either low activity or high activity together with low base saturation.

Evaluations were carried out throughout three productive cycles (2015-16; 2016-17; and 2017-18) of six blackberry bush genotypes: 'Tupy', 'BRS Xingu', Selection Black 178, Selection Black 128, Selection Black 112 and Selection Black 145. This material, which belongs to the improvement program developed by the Embrapa Clima Temperado, was implemented in 2014. Spacing was $3.0 \mathrm{~m}$ among rows and $0.50 \mathrm{~m}$ among plants, which were managed in an organic farming system, with neither irrigation nor a support system. Harvest started in November in the first two crops while the one in the third crop began a month earlier. In the three years under evaluation, the harvest period extended until January in the first two crops and until February in the third one.

Harvested fruit were shiny black, in the complete ripening stage (Antunes et al., 2010; Brugnara, 2016).

Production was evaluated by weighing all fruits yielded by useful plants. Mean plant weight was multiplied by plant density (6,666 plants). Accumulated production was the sum of the production of individual crops.

In this period, representative samples of every treatment, i. e., about 700 grams of every genotype with approximately 100 fruits, were separated. In order to carry out fruit characterization, parcels were harvested and stored separately in plastic containers which were taken to the Laboratory of Food Science and Technology at the Embrapa Clima Temperado, so as to be submitted to analyses of physico-chemical and mineral characteristics, bioactive compounds and antioxidant activity. Samples of 100 fruits per treatment were submitted to analyses of soluble solids, total soluble solids (TSS), hydrogenionic potential $(\mathrm{pH})$, total titratable acidity (TTA) and SS/TA ratio. In order to carry out these analyses, fruit juice was extracted by a domestic centrifuge.

Soluble solid content was collected by a digital refractometer. A drop of fruit juice was placed on the prism surface of the equipment to determine the amount of soluble solid content in every genotype, expressed as degrees ${ }^{\circ}$ Brix.

A benchtop pHmeter was used for measuring the hydrogenionic potential.

Total titratable acidity was measured by a digital burette, in agreement with the methodology based and adapted by Zenebon et al. (2008). Sodium hydroxide $(\mathrm{NaOH}) 0.1 \mathrm{~N}$ was slowly added to a beaker with $5 \mathrm{ml}$ blackberry juice and $90 \mathrm{ml}$ distilled water to carry out titration up to $\mathrm{pH} 8.1$ (potentiometric titration). Results were expressed as percentages of citric acid.

The SS/TA ratio is the relation between TSS and TTA which can be used for evaluating balance between acidity and sweetness.

The method used for determining phenolic compounds was adapted from Swain \& Hillis (1959). Regarding anthocyanins, the method adapted from Fuleki \& Francis (1968) was applied.

In order to determine the antioxidant activity of fruits yielded by blackberry bushes, the method adapted from Brand-Williams et al. (1995) was used.

For the determination of minerals ( $\mathrm{Ca}, \mathrm{Mg}, \mathrm{K}$, 
P, Cu, Fe, Mn and Zn), fruit samples were lyophilized by model L101 (Liobras) and crushed by mills (Willey). Then, digestion and quantification of minerals was carried out by atomic absorption spectrometry (model AA 240 FS Varian).

It was a randomized block design with three replicates; every parcel comprised eight plants. Samples of harvested fruits were processed homogeneously in every treatment. Replicates of readings of analyzed postharvest parameters were made. Data were submitted to the analysis of variance and then compared by the Tukey's test, at $5 \%$ significance, by the Sisvar ${ }^{\circledR}$ statistical program.

\section{Results and Discussion}

Throughout the evaluation of the three crops, accumulated production of all genotypes under study was registered (Table 1). Selection Black 178 exhibited the highest accumulated production, i.e., $32111.0 \mathrm{~kg}$. ha-1, and showed that this blackberry bush genotype adapted well to the edafoclimatic conditions in the region. Selection Black 128 had the lowest production: $16436.7 \mathrm{~kg}$. $\mathrm{ha}^{-1}$. However, this comparison is related to the selections and cultivars under study in experimental conditions. Interaction between the genotype and the environment is very important to the productive behavior of blackberry bush genotypes (Suzuki, 2013). Weather conditions may vary from year to year and every genotype may respond differently to fruit production and quality.

No relationship was observed between production and variables TSS, $\mathrm{pH}$, titratable acidity and SS/TA ratio.

Table 1. Accumulated production, expressed as $\mathrm{kg}$. ha-1, of six genotypes of blackberry bushes grown in an organic farming system in Pelotas, Rio Grande do Sul (RS), Brazil in three crops. Pelotas, RS, Brazil, 2017.

\begin{tabular}{ccccc}
\hline Genotype & $2015 / 2016$ & $2016 / 2017$ & $2017 / 2018$ & Accumulated yield \\
\hline Black 178 & 7844,45 & 10582,56 & 13684,00 & 32111,01 \\
Black 112 & 2673,34 & 3114,83 & 13892,00 & 19680,17 \\
Black 145 & 5400,00 & 5633,9 & 14806,01 & 25839,91 \\
Black 128 & 2431,11 & 7238,92 & 6766,67 & 16436,70 \\
'Xingu' & 4177,78 & 5136,44 & 13741,34 & 23055,56 \\
'Tupy' & 1768,90 & 4433,16 & 10405,34 & 16607,40 \\
\hline
\end{tabular}

In the first crop, soluble solid contents of genotypes under study did not show any significant difference (Table 2). However, there were differences among genotypes in the other crops. TSS content is variable, depending on the characteristics of the genotype, besides cultivation conditions and the weather, which varies from crop to crop (Hirsch et al., 2012; Tullio \& Ayub, 2013). In general, crops of the genotypes under study showed high TSS values (the mean was $9.2^{\circ}$ Brix). Selection Black 112 and Selection Black 128 were the genotypes that had the lowest TSS means in the period under evaluation: 7.5 and 7.4 , respectively. TSS content of Selection Black 145 was 9.0 'Brix, followed by 'Tupy' (8.3 'Brix) and 'BRS Xingu' (8.23 'Brix). Means of genotypes under study show variation between selections and cultivars of blackberry bushes, i. e., from 9.2 to $7.4^{\circ}$ Brix.

TSS can be used as an indicator of the sugar content found in fruit. This variable can also assist in the sensory analysis, indicating fruit that would be better for the fresh marker or the industry. Generally, cultivars with high TSS values are well accepted by consumers for fresh consumption. Variation observed between genotypes can be attributed to some factors, such as characteristics of the cultivar, influence of the place of cultivation and temperature (Ali et al., 2011; Hirsch et al., 2012; Guedes et al., 2013; Gabriel et al., 2019).
Values of $\mathrm{pH}$ ranged from 2.03 to 3.28 . Both Selection Black 178 (3.21) and Selection Black 128 (3.19) were the genotypes that exhibited the highest mean in this variable. Silva et al. (2014) also observed a little variation which ranged from 2.89 to 2.99 in samples of blackberry pulp, while Hirsch et al. (2012) found pH values that varied between 2.78 and 3.08. In experimental conditions, the cultivar 'Tupy' showed pH 2.65, one of the lowest values among the genotypes under study, along with the one of Selection Black 112 (2.72). According to Hirsch et al. (2012), blackberries have flavor that varies from acid to sweet-acid. The $\mathrm{pH}$ and other characteristics found in fruit can be used as indicators to define the best genotypes for the fresh market or industry.

Regarding total titratable acidity, Selection Black 145 had the highest mean value with $1.55 \%$ citric acid, followed by Selection Black 112 with $1.09 \%$ citric acid. The lowest values were exhibited by the cultivar 'Tupy' and Selection Black 128, i. e., 0.84 and $0.85 \%$ citric acid, respectively. According to Hirsch et al. (2012), organic acids, such as citric acid, affect mainly sensory properties and, consequently, fruit taste and smell. Cruz et al. (2017) observed that the cultivar 'Brazos' exhibited $1.03 \%$ citric acid. Variation in these values enables cultivars to be differentiated in terms of fruit taste. 
Table 2. Evaluation of pH, TSS, TA and SS/TA ratio of genotypes of blackberry bushes in three crops (2015, 2016 and 2017). Pelotas, RS, Brazil, 2017.

\begin{tabular}{ccccc}
\hline Genotype & $\begin{array}{c}\text { Total soluble solids } \\
\text { ('Brix) }\end{array}$ & $\mathrm{pH}$ & $\begin{array}{c}\text { Total titratable acidity } \\
\text { (\% citric acid) }\end{array}$ & Ratio SS/TA \\
\hline Black 178 & $6.90 \mathrm{~ns}$ & $2015-2016$ & $1.10 \mathrm{bc}$ & $6.26 \mathrm{bc}$ \\
Black 112 & 5.70 & $3.23 \mathrm{ab}$ & $0.95 \mathrm{c}$ & $3.60 \mathrm{~d}$ \\
Black 145 & 8.00 & $2.03 \mathrm{~b}$ & $1.74 \mathrm{a}$ & $3.51 \mathrm{~d}$ \\
Black 128 & 6.13 & $3.14 \mathrm{ab}$ & $0.80 \mathrm{~cd}$ & $8.38 \mathrm{a}$ \\
'Xingu' & 5.12 & $3.28 \mathrm{a}$ & $1.16 \mathrm{bc}$ & $6.90 \mathrm{~b}$ \\
'Tupy' & 6.70 & $3.10 \mathrm{ab}$ & $0.69 \mathrm{~d}$ & $5.47 \mathrm{c}$ \\
\hline Black 178 & $2.09 \mathrm{ab}$ & & \\
Black 112 & $9.20 \mathrm{~b}$ & $2016-2017$ & $0.97 \mathrm{c}$ & $9.46 \mathrm{~b}$ \\
Black 145 & $8.16 \mathrm{~b}$ & $3.21 \mathrm{ab}$ & $1.16 \mathrm{~b}$ & $8.14 \mathrm{c}$ \\
Black 128 & $9.93 \mathrm{a}$ & $3.19 \mathrm{~b}$ & $1.48 \mathrm{a}$ & $4.73 \mathrm{~d}$ \\
'Xingu' & $7.00 \mathrm{c}$ & $2.95 \mathrm{c}$ & $0.85 \mathrm{~cd}$ & $10.68 \mathrm{a}$ \\
'Tupy' & $9.46 \mathrm{a}$ & $3.15 \mathrm{~b}$ & $0.88 \mathrm{~b}$ & $8.56 \mathrm{c}$ \\
\hline Bupy & $9.40 \mathrm{a}$ & $3.28 \mathrm{a}$ & $0.79 \mathrm{~d}$ & $10.35 \mathrm{a}$ \\
Black 178 & $2.95 \mathrm{c}$ & & \\
Black 112 & $11.40 \mathrm{a}$ & $2017-2018$ & $0.77 \mathrm{e}$ & $14.75 \mathrm{a}$ \\
Black 145 & $8.60 \mathrm{e}$ & $3.18 \mathrm{a}$ & $1.16 \mathrm{~b}$ & $7.43 \mathrm{~d}$ \\
Black 128 & $9.10 \mathrm{c}$ & $2.93 \mathrm{c}$ & $1.42 \mathrm{a}$ & $6.43 \mathrm{e}$ \\
'Xingu' & $8.90 \mathrm{~cd}$ & $3.05 \mathrm{~b}$ & $0.90 \mathrm{~d}$ & $9.90 \mathrm{~b}$ \\
'Tupy' & $10.10 \mathrm{~b}$ & $3.13 \mathrm{a}$ & $1.12 \mathrm{~b}$ & $9.05 \mathrm{bc}$ \\
\hline * & $8.80 \mathrm{de}$ & $2.95 \mathrm{c}$ & $1.03 \mathrm{c}$ & $8.57 \mathrm{c}$ \\
\hline
\end{tabular}

Values of SS/TA ratio were significantly different among blackberry bush genotypes since they ranged from 3.51 to 14.75. This relation shows the balance between fruit acidity and sweetness. Selection Black 178 had the highest mean value (10.16) in all three crops, while Selection Black 145 showed a low relation (4.89), followed by the cultivar 'BRS Xingu' (4.09). Low relations indicate unbalance between fruit sweetness and acidity, with predominant acidity. In experimental conditions, the relation exhibited by cultivar 'Tupy' was 8.13. This result does not corroborate the one found by Brugnara (2016) in the same cultivar, whose ratio value was 7.09, in Chapecó, Santa Catarina state. According to Souza (2013), this variable is an important parameter to measure consumers' perception of taste. Brugnara (2016) states that the higher this relation is, the better the taste. Thus, values observed in the crops under evaluation show variation among genotypes and enable to distinguish the ones that have better balance between fruit sweetness and acidity.

According to Kader (1999), the ratio between SS/TA directly influences the acceptance of fresh fruit by consumers.

Fruits may be considered one of the main sources of elements that play an important and essential role in development and health, since their minerals are fundamental to human beings (Souza et al., 2015).

Results of mineral contents found in fruits are shown in Table 3. They varied among genotypes in the crops under evaluation. Concerning calcium (Ca) content, the cultivar 'Tupy' yielded the highest mean of all, i. e., $1.27 \mathrm{~g} \mathrm{~kg}^{-1}$, followed by Selection Black 112 , which exhibited $1.20 \mathrm{~g} \mathrm{~kg}^{-1}$. The lowest Ca content, which was $0.70 \mathrm{~g} \mathrm{~kg}^{-1}$, was found in fruits yielded by Selection Black 178. Mean Ca values of other genotypes were 1.08 $\mathrm{g} \mathrm{kg}^{-1}$ (Selection Black 145), $1.06 \mathrm{~g} \mathrm{~kg}^{-1}$ ('BRS Xingu') and $1.00 \mathrm{~g} \mathrm{~kg}^{-1}$ (Selection Black 128). Souza et al. (2015) found mean Ca values of $1.95 \mathrm{~g} \mathrm{~kg}^{-1}$ in blackberries yielded by the cultivar 'Tupy', while Guedes et al. (2013) found 1.16 $\mathrm{g} \mathrm{kg}^{-1}$ in fruits yielded by this cultivar. However, cultivars Xavante, Cherokee and Arapaho exhibited higher values, i. e., $2.33 \mathrm{~g} \mathrm{~kg}^{-1}, 2.21 \mathrm{~g} \mathrm{~kg}^{-1}$ and $2.02 \mathrm{~g} \mathrm{~kg}^{-1}$, respectively.

Calcium is a mineral that is directly related to fruit firmness and storage time. When very low calcium levels occur, they can cause shorter shelf life. Associated with increased respiratory metabolism, they result in the acceleration of fruit maturation and senescence process (Marschner, 1995; Aular \& Natale, 2013).

According to Nour et al. (2011), the mineral content found in fruit depends on some factors, such as soil, type of fertilization, climatic conditions and cultivar

Magnesium (Mg) contents in fruits varied among genotypes under study. Selection Black 145 stood out due to its mean value of $2.75 \mathrm{~g} \mathrm{~kg}^{-1}$, while the cultivar 'BRS Xingu' exhibited the lowest $\mathrm{Mg}$ content, i.e., $2.21 \mathrm{~g} \mathrm{~kg}^{-1}$.

Regarding potassium (K) contents, Selection Black 178 had the highest mean value $\left(15.75 \mathrm{~g} \mathrm{~kg}^{-1}\right)$ among the genotypes under study, followed by Selection 
Black 145 (15.67 $\mathrm{g} \mathrm{kg}^{-1}$ ) and 'BRS Xingu' (15. $\left.45 \mathrm{~g} \mathrm{~kg}^{-1}\right)$. The cultivar 'Tupy' exhibited mean K content of 14.29 $\mathrm{g} \mathrm{kg}^{-1}$, which was close to $14.52 \mathrm{~g} \mathrm{~kg}^{-1}$, the value shown by Selection Black 128. The lowest $K$ content found in fruits yielded by cultivars and selections under study was exhibited by Selection Black $112\left(13.62 \mathrm{~g} \mathrm{~kg}^{-1}\right)$. Guedes et al. (2013) carried out an experiment with different cultivars and found $K$ values ranging between 9.55 and $18.55 \mathrm{~g}$ $\mathrm{kg}^{-1}$ when they studied cultivars Ébano and Choctaw. Potassium content also may affect fruit firmness, soluble solids and fruit acidity (Kader, 2008; Guedes et al., 2013).

Table 3. Mineral contents of six genotypes of blackberry bushes grown in an organic farming system in Pelotas, Rio Grande do Sul (RS), Brazil, in crops 2016-2017 and 2017-2018. Pelotas, RS, Brazil, 2017.

\begin{tabular}{|c|c|c|c|c|c|c|c|c|}
\hline Genotypes & $\mathrm{Ca} \mathrm{g} \mathrm{kg}^{-1}$ & $\mathrm{Mg} \mathrm{g} \mathrm{kg}^{-1}$ & $\mathrm{~K} \mathrm{~g} \mathrm{~kg}^{-1}$ & $\mathrm{P} \mathrm{g} \mathrm{kg}^{-1}$ & Cu $\mathrm{mg} \mathrm{kg}^{-1}$ & $\mathrm{Fe} \mathrm{mg} \mathrm{kg}^{-1}$ & $\mathrm{Mn} \mathrm{mg} \mathrm{kg}^{-1}$ & $\mathrm{Zn} \mathrm{mg} \mathrm{kg}^{-1}$ \\
\hline \multicolumn{9}{|c|}{ 2016-2017 } \\
\hline Black 178 & $1.11 \mathrm{C}$ & $2.63 \mathrm{~b}$ & $13.96 \mathrm{ab}$ & 4.07 b & $8.04 \mathrm{~b}$ & $52.86 a$ & $29.90 \mathrm{~d}$ & $18.86 b$ \\
\hline Black 145 & $1.62 \mathrm{ab}$ & $3.42 \mathrm{a}$ & $15.12 \mathrm{a}$ & $3.50 \mathrm{bc}$ & $9.65 a$ & $47.72 \mathrm{~b}$ & $36.90 \mathrm{~b}$ & $23.26 \mathrm{a}$ \\
\hline Black 112 & $1.57 \mathrm{ab}$ & $2.53 \mathrm{~b}$ & $12.40 \mathrm{~b}$ & $5.32 a$ & $7.24 \mathrm{bc}$ & $43.77 \mathrm{c}$ & $33.40 \mathrm{c}$ & $19.23 \mathrm{~b}$ \\
\hline Black 128 & $1.46 \mathrm{bc}$ & $2.62 \mathrm{~b}$ & $12.62 \mathrm{~b}$ & $4.25 \mathrm{ab}$ & $6.62 \mathrm{C}$ & $45.83 \mathrm{bc}$ & $41.53 a$ & $18.68 \mathrm{~b}$ \\
\hline 'Xingu' & $1.79 \mathrm{ab}$ & $2.48 \mathrm{~b}$ & $13.65 \mathrm{ab}$ & $4.31 \mathrm{ab}$ & $7.78 \mathrm{~b}$ & $46.40 \mathrm{~b}$ & $42.72 a$ & $19.72 \mathrm{~b}$ \\
\hline 'Tupy' & $1.91 \mathrm{a}$ & $2.62 \mathrm{~b}$ & $13.16 \mathrm{~b}$ & $3.02 \mathrm{c}$ & $10.42 a$ & $48.05 \mathrm{~b}$ & $34.01 \mathrm{c}$ & $19.87 \mathrm{~b}$ \\
\hline \multicolumn{9}{|c|}{$2017-2018$} \\
\hline Black 178 & $0.28 d$ & $1.97 \mathrm{bc}$ & $17.53 \mathrm{a}$ & $8.88 \mathrm{a}$ & $2.25 \mathrm{~b}$ & $45.97 \mathrm{~ns}$ & $26.64 \mathrm{e}$ & $22.15 \mathrm{~ns}$ \\
\hline Black 145 & $0.54 \mathrm{bc}$ & $2.08 a$ & $16.22 \mathrm{bc}$ & $6.33 c$ & $2.08 \mathrm{~b}$ & 43.46 & $29.64 \mathrm{~d}$ & 21.86 \\
\hline Black 112 & $0.82 a$ & $2.07 a b$ & $14.84 \mathrm{~d}$ & $5.17 d$ & $2.20 \mathrm{~b}$ & 47.03 & $41.88 a$ & 23.65 \\
\hline Black 128 & $0.53 c$ & $2.01 \mathrm{abc}$ & $16.42 \mathrm{abc}$ & $6.90 \mathrm{~b}$ & $1.65 \mathrm{c}$ & 42.84 & $35.76 \mathrm{~b}$ & 23.26 \\
\hline 'Xingu' & $0.33 d$ & $1.93 \mathrm{C}$ & $17.25 \mathrm{ab}$ & $7.17 b$ & $2.41 \mathrm{ab}$ & 43.30 & $32.90 \mathrm{bc}$ & 22.44 \\
\hline 'Tupy' & $0.63 \mathrm{~b}$ & $1.97 \mathrm{C}$ & $15.42 \mathrm{~cd}$ & $8.37 \mathrm{a}$ & $2.93 a$ & 44.14 & $32.13 \mathrm{~cd}$ & 22.25 \\
\hline
\end{tabular}

Phosphorus $(\mathrm{P})$ contents found in the composition of fruits yielded by blackberry bushes ranged from 3.02 to $8.88 \mathrm{~g} \mathrm{~kg}^{-1}$. Selection Black 178 had the highest mean $\mathrm{P}$ content, i. e., $6.48 \mathrm{~g} \mathrm{~kg}^{-1}$, while Selection Black 145 exhibited the lowest one: $4.92 \mathrm{~g} \mathrm{~kg}^{-1}$. Souza et al. (2015) found P content of $1.47 \mathrm{~g} \mathrm{~kg}^{-1}$ in fruits yielded by 'Tupy' blackberry bushes in São Paulo state. Their result does not corroborate data found by the study reported by this paper, since the mean $P$ value was $5.70 \mathrm{~g} \mathrm{~kg}^{-1}$.

There was variation among genotypes regarding Copper (Cu) contents. Fruits yielded by the cultivar 'Tupy' had the highest mean Cu value, which was $6.68 \mathrm{mg} \mathrm{kg}^{-1}$, followed by Selection Black $145\left(5.87 \mathrm{mg} \mathrm{kg}^{-1}\right)$. The lowest Cu content was exhibited by Selection Black $128(4.14 \mathrm{mg}$ $\mathrm{kg}^{-1}$ ). Tosun et al. (2008) found mean Cu content of 10.66 $\mathrm{mg} \mathrm{kg}^{-1}$ in wild blackberries in Turkey.

Selection Black 178 had the highest mean iron (Fe) content: $49.42 \mathrm{mg} \mathrm{kg}^{-1}$. Fe contents varied among genotypes; the lowest mean value was $44.34 \mathrm{mg} \mathrm{kg}^{-1}$, which was found in fruits yielded by Selection Black 128. The other genotypes exhibited the following Fe contents: $46.10 \mathrm{mg} \mathrm{kg}^{-1}$ ('Tupy'), $45.59 \mathrm{mg} \mathrm{kg}^{-1}$ (Selection Black 145), $45.40 \mathrm{mg} \mathrm{kg}^{-1}$ (Selection Black 112) and $44.85 \mathrm{mg} \mathrm{kg}^{-1}$ ('BRS Xingu'). Fe content found by Tosun et al. (2008) in wild blackberries was $70.12 \mathrm{mg} \mathrm{kg}^{-1}$.

Manganese (Mn) contents found in fruits also varied among genotypes. Selection Black 128 exhibited the highest mean Mn content, which was $38.65 \mathrm{mg} \mathrm{kg}^{-1}$, while fruits yielded by Selection Black 178 had the lowest
Mn content (28.27 $\left.\mathrm{mg} \mathrm{kg}^{-1}\right)$. Selection Black 145 and the cultivar 'Tupy' had similar Mn values, i.e., $33.27 \mathrm{mg} \mathrm{kg}^{-1}$ and $33.07 \mathrm{mg} \mathrm{kg}^{-1}$, respectively. Since Selection Black 112 exhibited $37.64 \mathrm{mg} \mathrm{kg}^{-1}$, the difference between its mean value and the one found in the cultivar 'BRS Xingu' was just $0.16 \mathrm{mg} \mathrm{kg}^{-1}$.

Regarding zinc (Zn), the genotype with the highest content was Selection Black 145, whose value was $22.56 \mathrm{mg} \mathrm{kg}^{-1}$. Selection Black 178 yielded fruits with the lowest $\mathrm{Zn}$ content $\left(20.51 \mathrm{mg} \mathrm{kg}^{-1}\right)$, followed by Selection Black 128 (20.97 $\left.\mathrm{mg} \mathrm{kg}^{-1}\right)$. Other $\mathrm{Zn}$ contents were 21.44 $\mathrm{mg} \mathrm{kg}^{-1}$ (Selection Black 112), $21.08 \mathrm{mg} \mathrm{kg}^{-1}$ ('BRS Xingu') and $21.06 \mathrm{mg} \mathrm{kg}^{-1}$ ('Tupy'). Souza et al. (2015) studied the cultivar "Tupy" and found mean $\mathrm{Zn}$ content of $18.6 \mathrm{mg}$ $\mathrm{kg}^{-1}$ in blackberries.

Variation among genotypes in mineral contents may be attributed to some factors, such as soil conditions and fertilization methods, besides others that are intrinsic to the genotypes (Nour et al., 2011).

Concerning phenolic compounds and anthocyanins (Table 4), genotypes did not show any significant statistical difference in the 2016-17 crop. However, there was variation among genotypes under study. Selection Black 112 exhibited the highest mean value of phenolic compounds, i.e., $726.27 \mathrm{mg}$ chlorogenic acid equivalent/100 $\mathrm{g}$ fresh weight, while the cultivar 'Tupy' had the lowest phenolic compound content, which was 453.19 mg chlorogenic acid equivalent/100g fresh weight. Guedes et al. (2014) found 
results of phenolic content in blackberries yielded by the cultivar 'Tupy' of $247.33 \mathrm{mg} 100 \mathrm{~g}^{-1} \mathrm{FW}$ in the south of Minas Gerais state. Vizzotto et al. (2012) also evaluated bioactive compounds in fruits yielded by blackberry bushes and reported that the phenolic compound content of the cultivar 'Tupy' was $725.70 \mathrm{mg}$ chlorogenic acid equivalent/100g fresh weight. Since they found little variation among genotypes, results were different from the ones found by the study described by this paper.

Phenolic compounds found in fruits are beneficial to health, due to their antioxidant capacity. They can inactivate free radicals, thus contributing to prevent some diseases, such as cardiovascular, cancerous and neurological ones (Kuskoski et al., 2005; Silva et al., 2010; Jacques \& Zambiazi, 2011).

Variation in phenolic compound contents can be attributed to several factors, such as the species, cultivar, degree of fruit maturation, soil and climate conditions (Bravo, 1998; Musa et al., 2015).

Table 4. Phenolic compounds, anthocyanins and antioxidant activity found in fruits yielded by six genotypes of blackberry bushes grown in an organic farming system in Pelotas, Rio Grande do Sul (RS), Brazil, in crops 2016-2017 and 2017-2018. Pelotas, RS, Brazil, 2017.

\begin{tabular}{|c|c|c|c|}
\hline Genotypes & $\begin{array}{l}\text { Phenolic compounds } \\
\text { (mg chlorogenic acid } \\
\text { equivalent/100 g fresh weight) }\end{array}$ & $\begin{array}{c}\text { Anthocyanins } \\
\text { (mg cyanidin3-glucoside } \\
\text { equivalent/100 mg sample) }\end{array}$ & $\begin{array}{c}\text { Antioxidant activity } \\
\text { ( } \mu \mathrm{g} \text { trolox equivalent/g fresh weight) }\end{array}$ \\
\hline \multicolumn{4}{|c|}{$2016-2017$} \\
\hline Black 178 & $650.07 \mathrm{~ns}$ & $307.20 \mathrm{~ns}$ & $7363.11 \mathrm{ab}$ \\
\hline Black 145 & 636.50 & 283.74 & $7481.54 \mathrm{ab}$ \\
\hline Black 112 & 768.32 & 278.36 & 11520.59 a \\
\hline Black 128 & 662.08 & 252.65 & $7853.36 a b$ \\
\hline 'Xingu' & 649.93 & 325.82 & $7133.72 a b$ \\
\hline 'Tupy' & 517.63 & 356.82 & $5511.73 \mathrm{~b}$ \\
\hline \multicolumn{4}{|c|}{$2017-2018$} \\
\hline Black 178 & $603.84 a b$ & $262.21 \mathrm{ab}$ & $1651.75 a$ \\
\hline Black 145 & $558.21 \mathrm{ab}$ & 184.70 b & $1556.00 \mathrm{ab}$ \\
\hline Black 112 & $684.21 \mathrm{a}$ & $293.56 \mathrm{ab}$ & 1673.49 a \\
\hline Black 128 & $460.36 \mathrm{bc}$ & $361.15 \mathrm{a}$ & $1236.47 \mathrm{~b}$ \\
\hline 'Xingu' & $560.75 a b$ & $422.94 \mathrm{a}$ & $1299.92 a b$ \\
\hline 'Tupy' & $388.75 \mathrm{C}$ & $193.25 \mathrm{~b}$ & $724.14 \mathrm{C}$ \\
\hline
\end{tabular}

Anthocyanins found in fruits varied among genotypes. The highest mean value, which was 374.38 mg cyanidin3-glucoside equivalent/100mg sample, was found in the cultivar 'BRS Xingu', followed by Selection Black 128 (306.90 mg cyanidin3-glucoside equivalent/100mg sample). In the experimental conditions, the anthocyanin content exhibited by the cultivar 'Tupy' was $275.04 \mathrm{mg}$ cyanidin3-glucoside equivalent/100mg sample. These results do not corroborate the ones found by Guedes et al. (2014), who studied different cultivars of blackberry bushes and observed that the cultivar 'Tupy' exhibited anthocyanin content of $371.17 \mathrm{mg} 100 \mathrm{~g}^{-1} \mathrm{FW}$. Selection Black 145 was the genotype that had the lowest mean anthocyanin content in its fruits $(234.22 \mathrm{mg}$ cyanidin3glucoside equivalent/100mg sample).

Anthocyanins are red, violet and blue pigments found in fruits. They can capture free radicals, thus exercising antioxidant activity. Variation in the levels of anthocyanins can be attributed to the possibility of their degradation, caused by $\mathrm{pH}$, temperature and other factors (Degáspari \& Waszczynsky, 2004; Stoclet et al., 2004).

Regarding antioxidant activity, Selection Black
112 stood out, since its fruits showed $6597.04 \mu \mathrm{g}$ trolox equivalent/g fresh weight. Fruits yielded by the cultivar 'Tupy' exhibited the lowest mean value: $3117.94 \mu \mathrm{g}$ trolox equivalent/g fresh weight. Vizzotto et al. (2012) carried out an experiment with different genotypes and observed that the cultivar 'Tupy' had $8611.1 \mu \mathrm{g}$ trolox equivalent/g fresh weight., while 'Guarani' exhibited $10103.5 \mu \mathrm{g}$ trolox equivalent/g fresh weight. and Selection 16/96 showed $12604.8 \mu \mathrm{g}$ trolox equivalent/g fresh weight. Therefore, variation in antioxidant activity found in fruits yielded by blackberry bushes depends on the genotype under analysis.

\section{Conclusions}

Selection Black 145 yielded fruits with high acidity and low relation between soluble solids and acidity. Thus, they are recommended for the industry;

Selection Black 178 yielded fruits which showed the highest relation between contents of soluble solids and acidity. Thus, they are recommended for fresh consumption;

In general, Selection Black 145 stood out in the production of fruits with high mineral contents; 
Fruits yielded by 'BRS Xingu' had the highest anthocyanin contents;

Selection Black 112 exhibited fruits with the highest values of antioxidant activity and phenolic compounds.

\section{References}

Ali, L., Svensson, B., Alsanius, B.W., Olsson, M.E. 2011. Late season harvest and storage of Rubus berries- Major antioxidant and sugar levels. Scientia Horticulturae 129: 376-381.

Antunes, L.E.C., Gonçalves, E.D., Trevisan, R. 2010. Fenologia e produção de cultivares de amoreira-preta em sistema agroecológico. Ciência Rural 40:1929-1933.

Antunes, L.E.C., Pereira, I.S., Picolotto, L., Vignolo, G.K., Gonçalves, M.A. 2014. Produção de amoreira-preta no Brasil. Revista Brasileira de Fruticultura 36: 100-111.

Aular, J., Natale, W. 2013. Nutrição mineral e qualidade do fruto de algumas frutíferas tropicais: goiabeira, mangueira, bananeira e mamoeiro. Revista Brasileira de Fruticultura 35: 1214-1231.

Brand-williams, W., Cuvelier, M.E., Berset, C. 1995. Use of a free radical method to evaluate antioxidant activity. Lebensmittel-Wissenschaft und Technologie 28: 25-30.

Bravo, L. 1998. Polyphenols: chemistry, dietary sources, metabolism, and nutritional significance. Nutrition Reviews 56: 317-333.

Brugnara, E.C. 2016. Produção, época de colheita e qualidade de cinco variedades de amoreira-preta em Chapecó, SC. Agropecuária Catarinense 29: 71-75.

Cruz, M.C.M., Moreira, R.A., Fagundes, M.C.P., Santos, A.S., Oliveira, J., Souza, J.R. S. 2017. Qualidade de amorapreta produzida em diferentes épocas em condições de clima temperado úmido. Revista Brasileira de Ciências Agrárias 12: 142-147.

Degáspari, C.H., Waszczynskyj, N. 2004. Propriedades antioxidantes de compostos fenólicos. Visão Acadêmica 5: 33-40.

Fagherazzi, A.F., Kretzschmar, A.A., Macedo, T.A., Vignolo, G.K., Antunes, L.E.C., Kirschbaum, D.S., Gimenez, G., Zoppolo, R., Jofre, F., Rufato, L. 2017. La coltivazione dei piccoli frutti in sud America: non solo mirtilli. Rivista di Frutticoltura e di Ortofloricoltura 81: 44-47.

Fuleki, T., Francis, F.T. 1968. Quantitative methods for anthocyanins 1. Extraction and determination of total anthocyanin in cranberries. Journal of Food Science 33: 72-77.

Gabriel, A., Resende, J.T.V., Zeist, A.R., Resende, L.V., Resende, N.C.V., Zeist, R.A. 2019. Phenotypic stability of strawberry cultivars based on physicochemical traits of fruits. Horticultura Brasileira 37: 75-81.

Guedes, M.N.S., Abreu, C.M.P., Maro, L.A.C., Pio, R., Abreu, J.R., Oliveira, J.O. 2013. Chemical characterization and mineral levels in the fruits of blackberry cultivars grown in a tropical climate at an elevation. Acta Scientiaru
Agronomy 35: 191-196.

Guedes, M.N.S., Maro, L.A.C., Pio, R., Abreu, C.M.P., Pio, R., Patto, L.S. 2014. Composição química, compostos bioativos e dissimilaridade genética entre cultivares de amoreira (Rubus spp.) cultivadas no sul de Minas Gerais. Revista Brasileira de Fruticultura 36: 206-213.

Hirsch, G.E., Facco, E.M.P., Rodrigues, D.B., Vizzotto, M., Emanuelli, T., 2012. Caracterização físico-química de variedades de amora-preta da região sul do Brasil. Ciência Rural 42: 942-947.

Jacques, A.C., Zambiazi, R.C. 2011. Fitoquímicos em amora-preta (Rubus-spp). Semina: Ciências Agrárias 32: 245-260.

Kader, A.A. 1999. Fruit maturity, ripening, and quality relationships. Acta Horticulturae 485: 203-208.

Kader, A.A. 2008. Perspective flavor quality of fruits and vegetables. Journal of the Science of Food and Agriculture 88: 1863-1868.

Kist, B.B. 2018. Anuário brasileiro de fruticultura. Editora Gazeta, Santa Cruz do Sul, Brazil. 88 p.

Kuskoski, E.M., Asuero, A.G., Troncoso, A.M., Mancini-Filho, J., Fett, R. 2005. Aplicación de diversos métodos químicos para determinar actividad antioxidante em pulpa de frutos. Ciência e Tecnologia de Alimentos 25: 726-732.

Marschner, H. 1995. Mineral nutrition higher plants. Academic Press, London, UK. 674 p.

Musa, C.I., Weber, B., Galina, J., Lagemann, C.A., Souza, C.F.V., Oliveira, E.C. 2015. Teor de compostos bioativos em três cultivares de morangos cultivados em solo convencional no município de Bom Principio/ RS: sua importância para a saúde humana. Caderno Pedagógico 12:56-66.

Nour, V., Trandafir, I., Ionica, M.E. 2011. Ascorbic acid, anthocyanins, organic acids mineral content of some black and red currant cultivars. Fruits 66: 353-362.

Raseira, M.C.B., Franzon, R.C. 2012. Melhoramento genético e cultivares de amora-preta e mirtilo. Informe Agropecuário 33: 11-20.

Silva, M.L.C., Costa, R.S., Santana, A.S., Koblitz, M.G.B. 2010. Compostos fenólicos, carotenoides e atividade antioxidante em produtos vegetais. Semina: Ciências Agrárias 31: 669-682.

Silva, M.P., Gomes, F.S., Junior Freire, M., Cabral, L.M.C. 2014. Avaliação dos efeitos da radiação gama na conservação da qualidade da polpa de amora-preta (Rubus spp. L.). Revista Brasileira de Fruticultura 36: 620627.

Souza, A.V. 2013. Pós-colheita e processamento de amora-preta 'Tupy'. 86p. (Tese de Doutorado) Universidade Estadual Paulista, Botucatu, Brazil.

Souza, A.V., Rodrigues, R.J., Gomes, E.P., Gomes, G.P., Vieites, R.L. 2015. Caracterização bromatológica de 
frutos e geleias de amora-preta. Revista Brasileira de Fruticultura 37: 013-019.

Stoclet, J.C, Chataigneau, T., Ndiaye, M., Oak, M.H., El Bedoui, J., Chataigneau, M., et al. 2004. Vascular protection by dietary polyphenols. European Journal Pharmacology 500: 299-313.

Suzuki, E.T. 2013. Produção extemporânea de amorapreta com uso de reguladores vegetais e nitrato de potássio em regiões tropicais. 89p. (Dissertação de Mestrado) - Universidade Estadual Paulista, Botucatu, Brazil.

Swain, T., Hillis, W. E. 1959. The phenolic constituents of Prunus domestica i.- The quantitative analysis of phenolic constituents. Journal of Science and Food Agriculture 10: 63-68.

Tosun, I., Ustun, N.S., Tekguler, B. 2008. Mudanças físicas e químicas durante a maturação de frutos de amorapreta. Scientia Agricola 65: 87- 90.

Tullio, L., Ayub, R.A. 2013. Production of blackberry cv Tupy, depending on the intensity of proning. Semina. Ciências Agrárias 34: 1147-1152.

Vizzotto, M. 2012. Propriedades funcionais das pequenas frutas. Informativo Agropecuário 33: 84-88.

Vizzotto, M., Raseira, M.D.B., Pereira, M.C., Fetter, M.R. 2012. Teor de compostos fenólicos e atividade antioxidante em diferentes genótipos de amoreira-preta (Rubus sp.). Revista Brasileira de Fruticultura 34: 853-858.

Zenebon, O., Pascuet, N.S., Tiglea, P. 2008. Conservas vegetais, frutas e produtos de frutas. In: Instituto Adolfo Lutz. Métodos físicos- químicos para análise de alimentos. São Paulo, Brazil. 580-581p.

Conflict of Interest Statement: The authors declare that the research was conducted in the absence of any commercial or financial relationships that could be construed as a potential conflict of interest.

All the contents of this journal, except where otherwise noted, is licensed under a Creative Commons Attribution License attribuition-type BY. 